\title{
IS CHILD LIKE PARENT? EDUCATional ATtainMENT AND ETHNiC ORIGIN*
}

\author{
Ira N. Gang \\ Rutgers University and IZA, Bonn \\ Klaus F. Zimmermann \\ IZA, Bonn University and CEPR, London
}

August 1999

\begin{abstract}
The speed at which immigrants assimilate is the subject of debate. Human capital formation plays a major role in this discussion. This paper compares the educational attainment of second generation immigrants to those of natives in the same age cohort. Evidence using a large German data set suggests ethnicity does matter: the size of the ethnic network has a positive effect on educational attainment, and a clear pattern is exhibited between countries-of-origin and educational attainment even in the second generation. For the children of the foreign-born, parental schooling plays no role in making educational choices. However, for Germans, contrary to the general findings in the literature, there is a statistically significant difference in favor of father's education over mother's education.
\end{abstract}

JEL Classifications: I21, J15, J62

Keywords: Assimilation, ethnicity, migration, education, second generation migrants

Prof. Dr. Klaus F. Zimmermann

IZA and Bonn University

P.O. Box 7240

D-53072 Bonn

Germany

Email: Zimmermann@iza.org
Prof. Ira N. Gang

Economics Department

Rutgers University

75 Hamilton Street

New Brunswick NJ 08901-1248 USA

Email: gang@economics.rutgers.edu

*This paper was written while Ira Gang was visiting Germany under the auspices of an Alexander von Humboldt Fellowship and a Rutgers Competitive Fellowship leave and substantially revised while Klaus F. Zimmermann was a Dartmouth-German Distinguished Visiting Professor at Dartmouth College. We thank these organizations for their financial support, John Haisken - DeNew for excellent research assistance and Gail M. Alterman for her comments. We are also very grateful to Ronald G. Ehrenberg, a referee, Thomas Bauer, Francisco Rivera-Batiz and various seminar participants for many helpful comments and suggestions on ealier drafts. 


\section{Introduction}

Every parent is familiar with the variety of influences their children fall subject to, and the limits of their own direct influence. There is a conflict, or at least a potential conflict, between what parents want and can give to their children, and the role of societal forces that lay beyond parental control. This potential conflict is particularly acute in the immigrant community where the lines are often starkly drawn. Immigrant parents, while desiring the best of what their host country has to offer for their children, also want their children to inherit the best of their own ethnic heritage. Of course, there are immigrant parents who want nothing to do with the host country culture; and others who completely reject their own heritage and desire complete assimilation for their children. To what extent do children follow in their parents footsteps? How do the forces of parental and ethnic group influences stack up against the assimilationist and discriminatory forces of society?

In part, at issue is the length of time it takes for immigrants and their families to assimilate into the economic and social structure of the host country. There is now a large economics literature on the assimilation of immigrants in several countries. The literature primarily pays attention to first generation immigrants and the length of time it takes for them to achieve earnings parity with the native-born. There is also some evidence on inter-generational aspects of assimilation. While the evidence is mixed, for the United States it is clear that the 'traditional' depiction of a smooth transition into a homo-americanus is not accurate. Even in popular parlance the idea of America as a place where ethnic differences melt away does not hold sway. The popular perception clearly holds that though there is much individual variation, on average some ethnic groups do well and some do not. The explanations for this are legion. Whatever the Americanization process is, the simple imagery of the melting pot has long been displaced.

While the textbook story of a smooth Americanization process has been upset, such a 
picture never existed for Germany. For several decades Germany has been a major country of immigration. Depending on the measurement one uses, before unification non-citizens made up approximately 7\% of West Germany's population. As reviewed by Zimmermann (1995), there were two major types of migrants. One group are ethnic Germans who obtain German citizenship immediately as per the requirements of the German Basic Law. These ethnic German immigrants came permanently to Germany. The other major group of migrants to Germany were workers and their families who came under a "guestworker" program. Most of these ethnically non-German immigrants came from Turkey, Yugoslavia, Greece, Italy and Spain. By intention these were temporary migrants. Guestworkers were expected to leave after a few years, i. e., when the labor market conditions demanded it.

The reality of guestworker immigrants is that most of them are not temporarily in Germany. They bring their families, and raise second generation immigrants, i. e., those who are born in Germany or arrive as children but still carry a foreign passport. In 1984 the average male guestworker had been in Germany for almost 15 years. This phenomena has been long understood [Schmidt and Zimmermann (1992)].

Educational attainment is a crucial aspect of assimilation in Germany. Germany, like many other European countries, places a higher weight on the formal aspect of educational degrees than does the United States. Hence, without educational attainment equivalent to that of the German system, the integration of immigrants into the German economy is substantially more difficult. The importance of formal educational degrees makes assimilation into Germany an intergenerational matter.

Hence, in this paper we explore a central issue in the performance of immigrants: the educational attainment of demographically comparable groups. For the U.S., this issue has been analyzed by Schultz (1984). For our study on Germany, we make use of the German Socio- 
economic Panel (GSOEP). This data consists of Germans and immigrants into Germany and their families. In particular, we use this data in a way which allows us to compare Germans and the children of immigrants in their attainment of German education, and to examine the role of parental and societal influences in the formation of human capital. In this effort, we draw on the literature on assimilation and inter-generational transfers of human capital and their roles in determining earnings [see for example, Chiswick (1988), Borjas (1992)], and also on the literature on educational attainment [see for example, Schultz (1984), Stapleton and Young (1988), Angrist and Krueger (1991, 1992), Beller and Chung (1992), Gertler and Glewwe (1992), Jasso and Rosenzweig (1990), Haveman and Wolfe (1995), Gang (1997), HaiskenDeNew, Büchel and Wagner (1997), Glomm (1997), Binder (1998), Pradhan (1998), Glewwe (1999)]. This literature has contributed much to our knowledge of how the elements of household economics affect educational attainment, ${ }^{1}$ but has not gone into detail on the influences of parental ethnic capital and societal factors on educational attainment. This issue is particularly acute when considering immigrants. In part, we want to know whether the shock of immigration breaks or reinforces the connection to ones' heritage, as portrayed by parental and societal influences on educational attainment. And we want to know how different the children of immigrants are from their non-immigrant cohort.

In the next section, we outline and discuss the specific questions we approach in the remainder of the paper. Section III presents our theoretical analysis, while in Section IV we provide the details on our data and empirical analysis. Results from the analysis are discussed in Section V. In Section VI we summarize our results and take up some of the related policy issues.

${ }^{1}$ Chiswick and Miller (1994) have studied post-immigration educational acquisition by first generation immigrants in Australia. The nature of guestworker immigration results in very little post-immigration acquisition by first generation immigrants in Germany. 


\section{Outline of the Questions}

In 1950 there were relatively few non-Germans living in Germany. Their numbers began to swell in the early 1960's under the auspices of the various government sponsored guestworker programs, so that by 1984 (the year when the GSOEP, the micro data set we employ herein, was first generated) 1,425,798 Turks, 600,314 Yugoslavs, 287,099 Greeks, 545,111 Italians and 158,843 Spaniards were living in Germany representing $4.9 \%$ of the entire population. ${ }^{2}$ These people did not just wander haplessly into Germany. Their entry was a result of a policy decision to alleviate labor shortages in certain industries for certain types of labor at given wages [Schmidt and Zimmermann (1992), Zimmermann (1995)]. The guestworker programs were very specific treaties outlining who could come in and under what conditions, and whether or not and when families could join them.

The general perception of guestworkers is that they are primarily uneducated, at least relative to the norms in German society. They were, after all, recruited to perform largely manual work in blue collar jobs. This impression extends naturally to their spouses. While the children of guestworkers are required, under German law, to attend school, the general impression is that they are less serious and less intense in their school-going than their comparable German cohort, and that they leave school earlier.

How accurate is this general perception? Some insight is gained by examining Table 1, which outlines some of the major characteristics in our sample of the main ethnic groups in Germany. Our discussion is focussed on the post-war generation, i.e., those born after 1945,

${ }^{2}$ As discussed in Zimmermann (1995), a guestworker treaty was also concluded with Portugal (among several other countries), and by 1984 there were 82,911 Portuguese living in Germany. However, the Portuguese were not sampled in the GSOEP. 
and their educational attainment as of $1984 .{ }^{3}$ Later in the paper we will extensively discuss the sample and the exact definition of the variables.

Table 1 presents three measures of educational outcomes in Germany for those born after 1945 (for a full description of these variables, see the data section below). Total years of education is a measure of the productive time spent in German schools, including higher degrees. Germans spend the most time in German schools, on average 12.1 years, followed by Spaniards with 9.5 years, and then Greeks, Italians, Yugoslavs and Turks with, respectively, 8.9, 8.3, 8.0 and 7.6 years. ${ }^{4}$ While there is differentiation among the non-German ethnic groups, they are closer to each other than any group is to the Germans -- on average Germans receive 2.6 years more schooling than the next highest ethnic group.

Highest degree completed categorizes schooling into three groups -- those who receive no German degree, those who receive the basic mandatory degree, and those who complete at least one of the three types of high school degrees. Here the differentiation in completed German schooling between Germans and non-Germans, and among the ethnic groups, is brought out more clearly. $47 \%$ of Germans obtain at least a high school degree, and only $6 \%$ receive no degree at all. In contrast, only $6 \%$ of the Turks complete high school, while $43 \%$ receive no degree. While Germans and Turks are at the extremes, other ethnic groups falling inbetween, in terms of average attainment they reflect the Turks more than the Germans.

Our third measure of educational outcomes is vocational training received in Germany. The German vocational training system is held up as a model world-wide. It is a complex

${ }^{3}$ Our sample consists of those people in the 1984 foreigner's subsample of the GSOEP who entered Germany as children or were born in Germany, and their comparable German cohort.

${ }^{4}$ These average levels are partly affected by the arrival of some members of the foreigner's cohort after completion of some schooling outside of Germany. See below for a fuller discussion of this issue. 
system with many different facets and programs. A simple categorization is used to characterize vocational training -- whether the individual had received some vocational training or not. Again the pattern of degree completion is repeated, with $45 \%$ of the Germans receiving vocational training, only $17 \%$ of the Turks doing so, and other groups falling in-between.

These three measures seem to confirm the popular perception: Germans receive markedly more education than other ethnic groups in their same age cohort. Some of the possible explanations for this variation among ethnic groups can be seen in the variables at the bottom of Table 1. There is a large variation for the post-war children we are examining in the educational attainment of their parents. Among the first generation immigrants, $9 \%$ of Turkish men and $4 \%$ of Turkish women completed the basic schooling degree in Turkey, while $20 \%$ and $16 \%$ of first generation Yugoslav men and women, respectively, completed the basic schooling degree in Yugoslavia. For the Germans we see amazing inter-generational changes -- while $47 \%$ of the post-war generation completed some form of high school, only $12 \%$ of their fathers and $9 \%$ of their mothers did so. Table 1 also highlights second generation age differences at the time of immigration, immigrant gender differences, ${ }^{5}$ and the age distribution of the post-war generation by ethnic group. These are items we want to take into account in analyzing the accumulation of human capital and how it differs among ethnic groups.

Our working hypothesis is that the inter-group variation in educational outcomes is not simply a matter of discrimination -- the achievement of children in schools is subject to a number of influences. Parents' schooling may directly affect children's schooling. Parents are children's first teachers, and more educated parents may invest more in child quality. Moreover, family and culture may interface with the schooling environment in different ways for different ethnic groups [Nelson-Le Gall (1994)]. Social capital, the notion of the assets of the

${ }^{5}$ It is not clear why there are relatively few second generation Yugoslav males in the sample. 
neighborhood and sub-culture which are common to all members of that group, will be reflected in the network of community support, and the educational achievement of students will in part reflect the learning conditions and social support provided by their community [Stone and Wehlage (1994)]. Furthermore, competition among students for educational placement varies from cohort to cohort. Finally, the life experience of the student -- whether and when they sustained the shock of immigrating and its fallout -- will affect their educational attainment.

In the next section we develop the formal theory of how these influences affect educational outcomes. Following the development of the theory, section IV discusses how the concepts are operationalized.

\section{Theory}

This study of educational attainment draws on the concepts of social capital put forward by Chiswick (1988) and Borjas (1992), in which they employ versions of the household production model to discuss inter-generational influences in education, occupation and earnings. Chiswick (1988) incorporates into household production additional inputs, such as cultural preferences for education, the desire for future relative to present consumption, and parental investments in home production (including parents level of schooling).

The model of household production as related to schooling postulates children's educational attainment as one of the elements of the household utility function [eg., Beller and Chung (1992), Gertler and Glewwe (1992)]. Educational attainment, like other elements in the utility function, is produced with inputs from the market and parental time. The child quality investment model, outlined by Chiswick (1988), asserts that if two groups are the same save for the price of quantity relative to the quality of children, in the second generation we will observe differences in education, occupational attainment and earnings. This is because the group for 
which the cost of quantity relative to quality of children is higher, will invest more in fewer higher quality children. This then implies that group differences are relevant to studying the educational achievements of children.

To help organize our thinking about the determinants of educational attainment and ethnic origin, we rely on an elementary model of parents' educational choice. Although simple, this model will provide us with several substantial conclusions that can be tested. It also takes into account that data availability would not allow us to examine a much richer theoretical framework.

Assume that utility is derived from consumption $\mathrm{C}$ and educational attainment of the child E. A Stone-Geary utility function for the parents suggests

(1) $\log U(C, E)=(1-k) \log \left(C-C_{0}\right)+k \log \left(E-E_{0}\right), k>0$,

where $\mathrm{C}_{0}$ and $\mathrm{E}_{0}$ are the usual "committed" quantities below which consumption and educational attainment are not allowed to fall. While consumption goods are provided by the market at price $1, \mathrm{E}$ is home-produced with market inputs $\mathrm{X}$ (educational goods) at price $\mathrm{P}$, and household time $\mathrm{H}$ evaluated at the wage rate w. Home production technology is given by $\mathrm{H}=$ $\mathrm{a} E$ and $\mathrm{X}=\mathrm{b} \mathrm{E}$, where $\mathrm{a}$ and $\mathrm{b}$ are fixed efficiency parameters. For simplicity the husband works full time in the market while the wife divides her total time $\mathrm{T}$ between homework (educating the children) $\mathrm{H}$ and market work $\mathrm{L}$. The usual household budget constraint is

(2) $\mathrm{C}+\mathrm{P} X=w \mathrm{~L}+\mathrm{V}$,

where $\mathrm{V}$ is the exogenous income of the household (male labor income and total non-labor 
income). Taking into account the wife's time-constraint, $\mathrm{T}=\mathrm{H}+\mathrm{L}$, the modified budget constraint is

(3) $\mathrm{C}+\mathrm{P}_{\mathrm{E}} \mathrm{E}=\mathrm{W} \mathrm{T}+\mathrm{V}=\mathrm{Y}^{*}$,

where $\mathrm{P}_{\mathrm{E}}=(\mathrm{a} \mathrm{w}+\mathrm{b} \mathrm{P})$ and $\mathrm{Y}^{*}$ is the potential income of the household.

Hence, the demand for educational attainment is

(4) $\mathrm{E}=\mathrm{E}_{0}+\mathrm{k}\left(\mathrm{Y}^{*}-\mathrm{E}_{0} \mathrm{P}_{\mathrm{E}}-\mathrm{C}_{0}\right) / \mathrm{P}_{\mathrm{E}}$.

$\mathrm{E}_{0}$ captures the core (pre-market) quantity of educational units the household demands, while the second term on the right-hand-side tells us the number of education units the household will acquire in light of market conditions.

In the framework of our earlier discussion we would expect important differences with respect to assimilation and ethnicity. These will be captured largely in $\mathrm{E}_{0}$. We expect that educational preferences as captured by $\mathrm{E}_{0}$ are positively affected by the degree of the immigrant's assimilation. There are also likely to be differences in the social capital of ethnic groups as they adjust to the immigration country's preferences. To the extent there is male preference, educational attainment will be higher for males, though we may also expect this to differ in degree among ethnic groups. Also, other cultural differences, even in the second generation, may produce different educational preferences between immigrants and Germans, and among the immigrant groups.

Schooling attainment of parents may affect the educational preferences they have for their children, and hence k. Parents' educational levels further work through wage and income 
variables, as is captured in the second term on the right-hand-side. ${ }^{6}$ For instance, in terms of market prices and income, father`s education works directly via $\mathrm{Y}^{*}$ in equation (4); the effect is positive. However, mother`s education operates via $\mathrm{Y}^{*}$ and $\mathrm{w}$ and exhibits, hence, a smaller effect than father`s education. Finally, the efficiency parameters $(a, b)$, found in the denominator of this term (see the definition of $\mathrm{P}_{\mathrm{E}}$ ), should shift with the size of ethnic networks and educational competition. Social support from ethnic networks seems important for the performance of immigrants. Networks will ease assimilation, and hence also educational attainment. Educational competition forces households to improve the production efficiency of education in order to keep up relative standards. Our model thus also captures aspects of the competition non-Germans faced from their comparable German cohort for places in school.

Our model depicts a highly stylized household in which the father plays no direct role in the home production of education. The father's effect on the educational attainment of his children is through the income he earns in the market. Hence, father's education is important here to the extent it raises his earnings capacity. Mothers, however, can affect their children's educational attainment both by earning income in the market and by directly engaging in home production. In brief, for fathers only the income effect is operating, while for mothers both the income and substitution effects come into play. Hence, we expect from the model that father's education will have a more positive impact than mother's education on children's educational attainment.

${ }^{6}$ Schultz (1984) points out that without wealth in the equation, parental education variables are proxies for the efficiency with which parents can invest in children's education (a price effect) and the economic resources parents have available to invest in their children (an income effect). 


\section{The Data}

This study uses data from the German Socio-economic Panel (GSOEP), a yearly survey which is described in Wagner et. al. (1993). The first wave of data was collected in 1984, from which most of our information is taken. The GSOEP provides two sub-samples, the Germans and the foreigners. The foreigner sample contains representative households from those five largest groups of immigrants (Turks, Yugoslavs, Greeks, Italians and Spaniards) who came under the guestworker system in the early 1960s. From the sample of the foreigners we kept those who were born in Germany or who arrived before the age of 16, and who in 1984 were 17-38 years old. These are considered to be the second generation immigrants, as defined in Kossoudji (1989, p. 497). From the German sample we examine the same age cohort.

Ethnicity for those in the foreigners' sample is determined on the basis of the passport the individual carries. Some of those who are in the foreigners sample carry German passports, and one cannot readily identify their ethnicity. One explanation is that they are Germans who married foreigners and therefore, because of the structure of the data collection, may fall in the foreigner sample. In terms of educational attainment they are Germans. Another explanation is that these individuals belong to one of the five immigrant groups, but have obtained German passports. ${ }^{7}$ Assigning ethnicity to German passport holders who appear in the foreigners sample is problematic. Our compromise is: 1) married individuals with German passports in the foreigners sample were moved to the German sample; 2) unmarried individuals in the foreigners sample who carry German passports were assigned to the immigrant group of their household, though we kept the information that he/she holds a German passport. ${ }^{8}$ As already noted in

${ }^{7}$ Some immigrants were able to obtain German citizenship. Among the requirements is a long permanent stay in Germany. They are also required to give up their original citizenship.

${ }^{8}$ The cases in the foreigners sample were grouped by ethnicity. Technically, we assigned German passport holders in the foreigners sample to the immigrant group of the case before and 
Table 1, the total sample size is 4678 with 3895 Germans, 295 Turks, 76 Yugoslavs, 116 Greeks, 175 Italians and 121 Spaniards.

Three measures of German educational attainment are investigated and were already discussed in Section II by use of Table 1: total years of education, schooling level and vocational training. The continuous variable total years of education was calculated in several ways on the basis of data for each individual on the type of school attended. Instead of just adding the standard years for the various educational degrees, we use in this paper a more conservative measure that adjusts for "duplicate" degrees and discounts alternative postschooling degrees (vocational training, university and the like) by one year. There were no relevant difference using alternative measures of years of schooling in the statistical analysis.

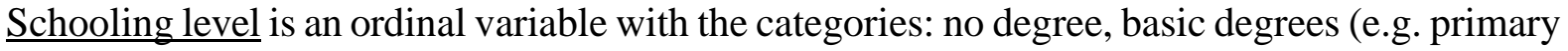
school), and at least a high school degree. ${ }^{9}$ Vocational training is a simple binary variable, indicating whether or not the individual has been in any type of formal vocational education.

Among the key exogenous variables are those representing parental human capital. This is given differentiated by gender using information that was obtained in the third wave of the panel in 1986. Since educational attainment in Germany is difficult to compare in its quality with educational levels of migrants acquired in their home countries, we decided to separate the variables for Germans and foreigners. For a foreigner, the parent's human capital dummy variable takes value 1 if its education is "basic schooling with degree" or above. ${ }^{10}$ In the case

after them.

${ }^{9}$ In Germany, the most important basic degree is Hauptschule, and high-school degrees include Realschule, Fachschule and Gymnasium.

${ }^{10}$ The number of years of compulsory schooling differs from country to country. In this time period they are approximately: Turkey, 5; Yugoslavia, 8; Greece, 9; Italy, 8; Spain, 8. See the discussion in Schultze (1969). 
of a German, the dummy takes value 1 if the parent has at least a high school degree. Other or missing observations were coded 0 .

Assimilation measures include a dummy variable for those with a German passport, a dummy variable for those born in Germany, and the age arrived in Germany (age-immigrated). The age-immigrated variable takes value 0 if born in Germany or if information on the time of arrival is missing. To account for the latter, we also included a age-immigrated missing dummy variable in the statistical analysis. In order to help capture the role of ethnic networks in schooling attainments, for each ethnic group we calculated the size of the stock of foreigners (divided by 10,000 ) in the respective ethnic groups over time in Germany (network). We assigned the value of network to the individual at the time when he/she was age 6 if he/she was in Germany at age 6 (i. e., Germany-born or immigrated before age 6), or the value of network at the time of immigration if this occurred after age 6 . To account for nonlinearities, network squared was also included in the analysis.

We constructed two variables, quantity of Germans and quality of Germans, from the GSOEP. These capture aspects of the competition non-Germans faced from their comparable German cohort for places in school. While Stapleton and Young (1988) argue crowding should decrease educational attainment, it may result in more efficient educational production. Quantity of Germans measures the number of Germans at the same age of the foreign individual, while for the same cohort quality of Germans measures the percentage of Germans who went on for at least a high-school degree. ${ }^{11}$ The social support and educational cohort

${ }^{11}$ The quantity of Germans is measured by looking at the absolute number of Germans in the GSOEP who were 6 years old during the year the second generation immigrant was 6 years old, or were the age the immigrant was when he or she arrived in Germany. To the extent the GSOEP is representative, the year to year variation in the number of German children reflects changes in the population of children. The quality of Germans was obtained by calculating the percentage of Germans in this group who eventually obtained a Realschule, Fachschule or Abitur. 
variables take value 0 for Germans.

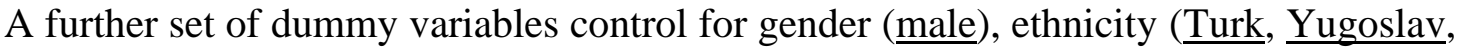

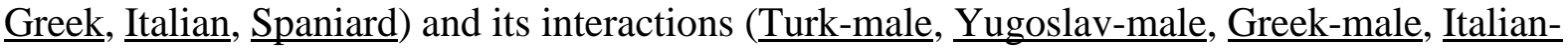
male, $\underline{\text { Spaniard-male)}}$. Other individual controls are age, age-squared, a dummy variable for $\underline{\text { still-in-school and its interactions age times still-in-school and age-squared times still in school, }}$ and dummy variables for being disabled and for having a foreign education (foreign-schooling).

\section{Empirical Analysis}

Since the endogenous variables are continuous (total years of education), ordinal (level of schooling) and binary (vocational training), we use OLS, ordinal Probit and binomial Probit as the respective estimation techniques. The Breusch-Pagan Lagrange multiplier test indicates heteroskedasticity in the OLS case, and White t-values are given. In both probit estimations, we also examined the heteroskedasticity issue using an exponential error specification [see Greene (1993), p. 649] depending on the driving variable age. Log-likelihood ratio tests between the heteroskedastic probit models to the variants without heteroskedasticity suggested use of the general model in the case of the schooling level analysis only. In the probit cases the Pseudo- $\mathrm{R}^{2}$ of Veall and Zimmermann (1992) is calculated. All results are summarized in Table 2.

Parental human capital has an effect on the educational attainment of the next generation in the case of the Germans only. Moreover, for Germans, father's education has a more important influence on educational attainment than mother's education. This result is in contrast to the literature [Haveman and Wolfe (1995)]. ${ }^{12}$ It is, however, consistent with the theoretical

\footnotetext{
${ }^{12}$ The evidence is not unambiguous. Haveman and Wolfe (1995) are making a judgement based on the preponderance of evidence. Gang (1997) finds that in Germany, Hungary and the Former Soviet Union, the results vary by subgroup of the population and gender.
} 
model provided in section II. In our model we argued that for father's education only the income effect operates, while for mother's education there is the additional and moderating influence of the substitution effect. It is the mother who is primarily engaged in the educational production inside the household.

Whereas parent's education has a positive impact on both total years of education and the schooling level, vocational training is affected negatively. This is not surprising. Recall that our measure of a German's parents education is whether or not parents have at least a high school education. Thus, highly educated parents have children who generally choose forms of education other than vocational training.

Migrants' education has no effect on the educational attainment of their children. The shock of immigration removes the inter-generational transfer of human capital through this mechanism. That is, the effects of schooling of first-generation immigrants is completely depreciated. With regard to their families educational background, second generation migrants have an equal start in the educational system of Germany. In addition, Schultz (1984) also finds that in the United States native-born parent's schooling affects their offsprings' educational attainments, with the effect of mothers's schooling being about twice as great as that of father's. However, among immigrants, generally, the relationship was weaker than for the native-born.

Ethnicity does matter for the second generation migrants as suggested by the model via the minimum required educational attainment and the production technology parameters. These various channels can be detailed as follows. The size of the ethnic network has an inverted Ushape effect on total years of education and on the schooling level. A female Turk has about 7 years less German education than an otherwise similar German woman. Next are Italians (6 years), Yugoslavs (4.5), Greeks (4), and Spaniards (2). Whereas males in general get half a year more education than their female ethnic counterparts, the Turkish man has in total about 2 more 
years. There is a similar tendency for the level of schooling and vocational training. Second generation male immigrants receive less vocational training than their German counterparts. Immigrant males are closer to German males in vocational training than are immigrant females to German females. With respect to the schooling level, we find no difference between the sexes; Turkish and Italian women have a lower level, Turkish men a lower level than the average individual, and Turkish women still lower. While men in the various ethnic groups attain higher schooling levels than women, the difference is only significant between Turkish men and women.

The attainment of a German passport is a clear indicator for positive integration in the German educational system. The estimates are positive for all three of our measures of educational attainment. Age-immigrated is clearly negatively related with all measures of educational attainment. The variable age-immigrated missing is negative and significant in all cases. It probably measures unobserved human capital components; those with higher levels of education are more likely to report. Born in Germany is significant only in the OLS regression, here with a negative sign. A second generation female has 3 years less education than a German woman, but about as much as a female foreigner arriving at age 6 . This lends support to our working assumption that we include in second generation immigrants not only those who were born in Germany, but also those who were young at the time of immigration. These two groups behave in the same way.

Generally, competition in numbers and quality from Germans has little effect on the efficiency of the production of education in immigrant households, and hence on the educational attainment of second generation immigrants. Where there is an effect (a quantity effect on years of education and a quality effect on vocational training), they appear to be complements. Our model predicts this: if there is more schooling competition, $\mathrm{H}$, the nonmarket (household) time, 
should decrease. That is, the production of educational attainment becomes more efficient.

All findings on the control variables are consistent and reasonable. Among these variables, the dummy variable disabled shows a negative and significant effect on all educational measures. Foreign-schooling has a negative effect on years of German education and schooling level, but no effect on vocational training. Those people still-in-school have lower levels of schooling, but the amount of education increases with age, while the increments of the increase become smaller.

We see the still-in-school variable primarily as a control variable that also captures cohort effects. Schooling is a behavioral choice. Excluding those who have made this choice would require us to model the sample selection process, or to restrict the sample to a narrower age group (i.e. 27-38), so as to deal with only those who are beyond this decision. This would result in a substantial reduction in the sample size. The number of people in school is significant, but still small. Furthermore, the way we have coded the variables alleviates most concerns with the inclusion of those still in school in our sample. At age 17, even when still-inschool, we already know what schooling degree (no degree, basic degree, at least one of the high-school degrees) the individuals have, and whether or not they have been or are in vocational training. Hence, there are no problems with the probit-type regressions.

However, one may argue that we have a censored sample in terms of the total years of schooling model. Controlling for whether or not one is still in school may not seem fully adequate, even with the non-linear specification we have used. Note, however, first, the qualitative conclusions between the OLS (total years in education) and the ordinal probit (school levels) regressions are not really different, although the variables measure somewhat different types of education and training. Second, note that as reported in section IV, we studied a larger number of different methods of calculating the total number of years in education from 
the educational categories in the survey without any noticeable differences in the final statistical analysis. Third, note that if this is an issue, then the parameter estimates would be downward biased and our results conservative. Hence, we are quite confident that our findings are stable.

On a conceptual level, there could be other problems with the measurement of the effects that are predicted by the theoretical model. For one thing there could be ethnic differences in employment rates for men. Wage changes under constrained labor supply also produce only income effects, but the wage variation would probably be different than that implied by the permanent income notion of formal education. That is to say, the variation in father's education may not be sufficient in the empirical specification. This would be a problem, since there are no other measures of income for parents in the data set. However, migrants in the sample are mostly those from the German guestworker program that selected foreign blue-collar workers, mostly male, who had similar qualifications and received the same wage as native blue-collar workers. Hence, by definition, all migrants were initially working at the beginning. Of course, this does not rule out a differentiation in labor force behavior across ethnic groups over time, but most of the non-successful workers returned home.

Another issue is that the wage opportunities for women in the German labor market are less attractive than those for men. Within the household, this would naturally encourage relatively more home production for women and hence more time devoted to enhancing the child's education. Although we assume complete specialization by gender, the actual extent of specialization varies across households as the relative market wages for mothers and fathers vary. A more complicated environment would include an equilibrium marital sorting process that takes into account relative market opportunities. However, this is beyond the present scope of the paper and the potential of this data set (and any other for Germany). 


\section{Summary and Conclusion}

Departing from most of the literature, this paper examines the educational aspect of assimilation of immigrants rather than the labor market outcomes of assimilation. We study their educational attainment as compared to the native-born. Most of the guestworkers who came to Germany from the late 1950s until the early 1970s completed their schooling prior to immigrating. Of interest, however, is the educational attainments of their children. Achieving parity in educational attainment is a central issue in the inter-generational performance of immigrants and their families. This is especially so in economies like Germany, where a very high weight is placed on the formal aspect of educational degrees. Without education equivalent to that of the German system, the integration of immigrants into the German economy is substantially more difficult.

Our empirical work is motivated by presenting a highly stylized version of a simple Becker allocation of time model in which the household seeks to maximize utility over two activities: consumption and educational attainment of the children. The latter activity is produced with the input of market goods and the mother's time. It is assumed that the father's labor supply is exogenous and set at full time employment so that changes in market wages have only an income effect for the father in terms of increasing the household's demand for child education. On the other hand, the mother's labor supply is endogenous so that wage changes have both income and substitution effects on the demand for child education. The model also covers potential ethnic differences by clarifying the potential channels through which these differences might have an effect: preferences and production technology.

We exploit the German Socio-economic Panel data set to compare educational attainments along three dimensions between various ethnic immigrants and indigenous Germans. These are (1) total years of education in the German school system, (2) 
categorical/hierarchical schooling levels attained in Germany, and (3) the receipt or absence of vocational training in Germany. The sample taken from the data set pertain to 17-38 year olds in 1984. Hence, it is focused on the post-war generation, i.e. those born after 1945. Our major findings are (1) that ethnic differences remain even after controlling for the influences of parental human capital, social support, assimilation measures, and competition from indigenous Germans within one's educational cohort, and (2) parental education has no independent effect on the educational outcomes of immigrants, while for Germans father's education has a larger impact than mother's education.

Ethnic origin matters significantly in educational attainment. Germans, Italians, Yugoslavs, Turks, Greeks and Spaniards in Germany have very different educational experiences. Recent theory suggests that parents exhibit a most important influence on children's educational outcomes. The influence of parents is usually captured by the parent's schooling -- the assumption is made that more educated parents invest more in their children's education. For Germans, the educational achievement of parents affects children's involvement in schooling. However, for the children of immigrants the family's investment in the formation of education is not dependent on parent's education.

Does our result mean that immigrant parents do not influence their children's educational outcomes? Probably not. For second generation immigrants, parental education is probably not a good proxy for parental influence. The decision by their parents to immigrate in the first place is a better indicator of parental influence. The shock of immigration eliminates the intergenerational consequences of parents' educational background. Put another way, the human capital investment parents have made by immigrating swamps the effects of the human capital investments in the formal schooling they and their parents had made earlier.

We find it worth noting that in contrast to recent evaluations in the literature - but in line 
with the early study by Schultz (1984) - father's education is more important than mother's education for the educational attainment of German children. Although this result might look surprising at the first sight, this is consistent with the theoretical framework outlined in the paper. Educating children in Germany is primarily a duty of the mother. An increase in the potential wage associated with her education may increase the demand for a higher educational attainment of the child, as it does for father's. However, this rise also implies a burden, since it causes a rise in the cost of home production. Hence, the total effect is smaller for the mother than for the father.

The family is not a self-contained unit; children are influenced by their community and the larger society in which they live, as argued especially by Chiswick (1988) and Borjas (1992). Our results indicate community and society do effect educational attainment. For nonGermans, the size of their ethnic group's presence at the time they enter the German school system makes a difference: the larger is the network, the more schooling is attained (up to a point). Vocational training, however, is not affected by the size of the ethnic group in Germany. Gender and ethnic group have independent and interactive effects on educational attainment. Furthermore, the longer the migrants live in Germany, the higher is the level of educational outcome.

One interpretation of our results is that the adjusted ethnic differences in educational attainment are the result of taste factors. However, it could be that some of the ethnic differences might be explained by selection effects operating with respect to the parents of the immigrant offspring studied in this sample. Lower skilled workers tend to migrate to countries with a more equal distribution of income, whereas the opposite tends to hold for higher skilled workers. In the case of Germany, the guestworker program is directed at lower skilled workers. Ethnic differences might to some extent reflect the selection effects of different degrees of 
income inequality of the sending countries. Another issue is whether there are any significant differences between immigrants' parents who took the guestworker program at face value, i.e., as a short term job abroad, and those whose expectations were that their stay in Germany would be indefinite. However, guestworker immigration stopped in Germany in 1973. Data collection for the GSOEP began in 1984. Those who "survived" in Germany to make it into the sample would be those there for the long term.

The assimilation literature measures assimilation by earnings and occupational attainment, emphasizing the role of human capital, investment in human capital and how human capital investment is conditional on the social structure of an immigrant group. We have focused on human capital formation, and look at the formation of human capital, i. e., educational attainment, by the cohort for whom we should observe significant assimilation -second generation foreigners (those born in Germany or migrated before age 17). Their attainment is contrasted to Germans of the same age cohort.

Assimilation in the acquisition of education is taking place. Second generation immigrants possess educational profiles that are closer to their comparable German cohort than their parents had in comparison to Germans in the parents' cohort. Moreover, the intergenerational differences in educational attainment between first generation immigrants and their children is greater than the differences between the children and their comparable German cohort. However, ethnicity still has a strong effect on educational attainment. Germany is a not a melting pot; it is a multicultural society in which social and cultural differences, at least as pertains to educational attainment, persist. 


\section{References}

Angrist, Joshua D. and Krueger, Alan B. "The Effect of Age at School Entry on Educational Attainment: An Application of Instrumental Variables with Moments From Two Samples." Journal of the American Statistical Association, 1992, 87, pp. 328-336.

Angrist, Joshua D. and Krueger, Alan B. "Does Compulsory School Attendance Affect Schooling and Earnings." The Quarterly Journal of Economics, 1991, 106 (4), pp. 979-1014.

Beller, Andrea H. and Chung, Seung-Sin. "Family Structure and Educational Attainment of Children." Journal of Population Economics, February 1992, 5 (1), pp. 39-59.

Binder, Melissa. "Family Background, Gender and Schooling in Mexico." Journal of Development Studies, 1998, 35 (2), 54-71.

Borjas, George J. "Ethnic Capital and Intergenerational Mobility." Quarterly Journal of Economics, February 1992, 107 (1), pp. 123-150.

Chiswick, Barry R. and Miller, Paul W. "The Determinants of Post-Immigration Investments in Education." Economics of Education Review, 1994, 13 (2), 163-177.

Chiswick, Barry R. "Differences in Education and Earnings across Racial and Ethnic Groups: Tastes, Discrimination, and Investments in Child Quality." Quarterly Journal of Economics, August 1988, 103 (3), pp. 571-597.

Gang, Ira. N. "Schooling, Parents and Country." Quarterly Journal of Economic Research, 1997, 66 (1), 180-186.

Gang, Ira. N. and Zimmermann, Klaus F. "Is Child Like Parent? Educational Attainment and Ethnic Origin.” CEPR Discussion Paper No. 1461, 1996.

Gertler, Paul and Glewwe, Paul. "The Willingness to Pay for Education for Daughters in Contrast to Sons: Evidence from Rural Peru." The World Bank Economic Review, January 1992, 6 (1), pp. 171-188.

Glewwe, Paul. "Why Does Mother's Schooling Raise Child Health in Developing Countries? Evidence from Morocco.” Journal of Human Resources, 1999, 34 (1), 124-59.

Glomm, Gerhard. "Parental Choice of Human Capital Investment." Journal of Development Economics, 1997, 53 (1), 99-114.

Greene, William H. Econometric Analysis. New York: Macmillan, 1993.

Haisken-DeNew, John; Büchel, Felix and Wagner, Gert G. "Assimilation and Other Determinants of School Attainment in Germany: Do Immigrant Children Perform as Well as Germans?" 1997, 66 (1), 169-179.

Haveman, Robert and Wolfe, Barbara “The Determinants of Children's Attainments: A Review 
of Methods and Findings." Journal of Economic Literature, December 1995, 33 (4), pp. 18291878.

Jasso, Guillermina and Rosenzweig, Mark R. The New Chosen People: Immigrants in the United States. New York: Russel Sage Foundation.

Kossoudji, Sherrie A. "Immigrant Worker Assimilation: Is It a Labor Market Phenomenon ?" Journal of Human Resources, Summer 1989, 24 (3), pp. 495-527.

Nelson-Le Gall, S. "Addressing the Continuities and Discontinuities Between Family and School for Ethnic Minority Children", in Francisco L. Rivera-Batiz, ed., Reinventing Urban Education: Multiculturalism and the Social Context of Schooling. New York: IUME Press, 1994.

Pradhan, Menno. "Enrolment and Delayed Enrolment of Secondary School Age Children in Indonesia." Oxford Bulletin of Economics \& Statistics, 1998, 60 (4), 413-30.

Schmidt, Christoph M. and Zimmermann, Klaus F. "Migration Pressure in Germany: Past and Future", in Klaus F. Zimmermann, ed., Migration and Economic Development. Berlin: Springer, 1992, pp. 201-230.

Schultz, T. Paul "The Schooling and Health of Children of U.S. Immigrants and Natives", in T. Paul Schultz and Kenneth J. Wolpin, eds., Research in Population Economics, 1984, 5, pp. 251288.

Schultze, Walter, Hrsg. Schulen in Europa. Band III - Teil B. Weinheim: Verlag Julius Beltz

Stapleton, David C. and Young, Douglas J. "Educational Attainment and Cohort Size." Journal of Labor Economics, July 1988, 6 (3), pp. 330-361.

Stone, C. and Wehlage, G. "Social Capital, Community Collaboration, and the Restructuring of Schools", in Francisco L. Rivera-Batiz, ed., Reinventing Urban Education: Multiculturalism and the Social Context of Schooling. New York: IUME Press, 1994.

Veall, Michael R. and Zimmermann, Klaus F. "Pseudo-R ${ }^{2 \prime s}$ in the Ordinal Probit Model." Journal of Mathematical Sociology, 1992, 16, pp. 333-342.

Wagner, Gert G. ; Burkhauser, Richard V., and Behringer, Friederike. "The English Language Public Use File of the German Socio-Economic Panel." Journal of Human Resources, Spring 1993, 28 (2), pp. 429-433.

Zimmermann, Klaus F. "Tackling the European Migration Problem", Journal of Economic Perspectives, Spring 1995, 9 (2), pp. 45-62. 
$\underline{\text { Table } 1}$

Characteristics of $17-38$ years old individuals in $1984^{\mathrm{a}}$

\begin{tabular}{|c|c|c|c|c|c|c|}
\hline & Germans & Turks & Yugoslavs & Greeks & Italians & Spaniards \\
\hline Sample size & 3895 & 295 & 76 & 116 & 175 & 121 \\
\hline \multicolumn{7}{|c|}{ Educational outcomes in Germany } \\
\hline $\begin{array}{l}\text { Total years of } \\
\text { education }\end{array}$ & $\begin{array}{l}12.1 \\
(2.5)\end{array}$ & $\begin{array}{c}7.6 \\
(4.2)\end{array}$ & $\begin{array}{c}8.0 \\
(4.8)\end{array}$ & $\begin{array}{c}8.9 \\
(4.4)\end{array}$ & $\begin{array}{c}8.3 \\
(4.4)\end{array}$ & $\begin{array}{c}9.5 \\
(3.9)\end{array}$ \\
\hline \multicolumn{7}{|c|}{ Highest degree completed (\% receiving) } \\
\hline no degree & $\begin{array}{c}6 \\
(23)\end{array}$ & $\begin{array}{c}43 \\
(50)\end{array}$ & $\begin{array}{c}38 \\
(49)\end{array}$ & $\begin{array}{c}32 \\
(47)\end{array}$ & $\begin{array}{c}35 \\
(48)\end{array}$ & $\begin{array}{c}24 \\
(43)\end{array}$ \\
\hline basic degree & $\begin{array}{c}47 \\
(50)\end{array}$ & $\begin{array}{c}51 \\
(50)\end{array}$ & $\begin{array}{c}38 \\
(49)\end{array}$ & $\begin{array}{c}41 \\
(49)\end{array}$ & $\begin{array}{c}53 \\
(50)\end{array}$ & $\begin{array}{c}60 \\
(49)\end{array}$ \\
\hline $\begin{array}{l}\text { high school } \\
\text { and above }\end{array}$ & $\begin{array}{c}47 \\
(50)\end{array}$ & $\begin{array}{c}6 \\
(25)\end{array}$ & $\begin{array}{c}24 \\
(43)\end{array}$ & $\begin{array}{c}27 \\
(44)\end{array}$ & $\begin{array}{c}13 \\
(33)\end{array}$ & $\begin{array}{c}17 \\
(37)\end{array}$ \\
\hline $\begin{array}{l}\text { Vocational training } \\
\text { (\% receiving) }\end{array}$ & $\begin{array}{l}45 \\
(50)\end{array}$ & $\begin{array}{c}17 \\
(38)\end{array}$ & $\begin{array}{c}28 \\
(45)\end{array}$ & $\begin{array}{c}18 \\
(39)\end{array}$ & $\begin{array}{c}30 \\
(46)\end{array}$ & $\begin{array}{c}33 \\
(47)\end{array}$ \\
\hline \multicolumn{7}{|l|}{ Other characteristics } \\
\hline Age & $\begin{array}{l}27.0 \\
(6.3)\end{array}$ & $\begin{array}{l}21.1 \\
(4.1)\end{array}$ & $\begin{array}{l}23.0 \\
(5.6)\end{array}$ & $\begin{array}{l}22.2 \\
(4.3)\end{array}$ & $\begin{array}{l}23.0 \\
(4.8)\end{array}$ & $\begin{array}{l}23.5 \\
(5.1)\end{array}$ \\
\hline Gender ( $\%$ male $)$ & $\begin{array}{c}49 \\
(50)\end{array}$ & $\begin{array}{c}55 \\
(50)\end{array}$ & $\begin{array}{c}39 \\
(49)\end{array}$ & $\begin{array}{c}53 \\
(50)\end{array}$ & $\begin{array}{l}55 \\
(50)\end{array}$ & $\begin{array}{c}58 \\
(50)\end{array}$ \\
\hline Father educated (\%) & $\begin{array}{l}12^{\mathrm{b}} \\
(32)\end{array}$ & $\begin{array}{c}9 \\
(29)\end{array}$ & $\begin{array}{c}20 \\
(40)\end{array}$ & $\begin{array}{c}10 \\
(31)\end{array}$ & $\begin{array}{c}12 \\
(33)\end{array}$ & $\begin{array}{c}16 \\
(37)\end{array}$ \\
\hline Mother educated (\%) & $\begin{array}{c}9^{\mathrm{b}} \\
(28)\end{array}$ & $\begin{array}{c}4 \\
(21)\end{array}$ & $\begin{array}{c}16 \\
(37)\end{array}$ & $\begin{array}{c}9 \\
(28)\end{array}$ & $\begin{array}{c}9 \\
(29)\end{array}$ & $\begin{array}{c}12 \\
(32)\end{array}$ \\
\hline $\begin{array}{l}\text { Age-immigrated, if } \\
\text { not born in Germany }\end{array}$ & & $\begin{array}{l}11.0 \\
(3.5)\end{array}$ & $\begin{array}{c}9.7 \\
(3.8)\end{array}$ & $\begin{array}{c}8.5 \\
(4.0)\end{array}$ & $\begin{array}{c}9.4 \\
(4.3)\end{array}$ & $\begin{array}{c}9.3 \\
(4.0)\end{array}$ \\
\hline
\end{tabular}

a Numbers in parentheses are standard deviations. A detailed description of the variables is given in the text.

b Not comparable to the other numbers in the row. For Germans, the percentage with at least a high school degree. For the others, the percentage with at least the basic schooling degree in their country-of-origin.

Source: SOEP, 1984, 1986, own calculations. 


\section{$\underline{\text { Table } 2}$}

Estimates of German Educational Attainment ${ }^{\mathrm{a}}$

\begin{tabular}{ccccc}
$\begin{array}{c}\text { Relevant } \\
\text { group,0 } \\
\text { otherwise }\end{array}$ & $\begin{array}{c}\text { Means of } \\
\text { Regressors }\end{array}$ & $\begin{array}{c}\text { Total } \\
\text { years } \\
\text { OLS }\end{array}$ & $\begin{array}{c}\text { Schooling level } \\
\text { Ordinal Probit }^{\mathrm{b}}\end{array}$ & $\begin{array}{c}\text { Vocational } \\
\text { Training } \\
\text { Binomial } \\
\text { Probit }\end{array}$ \\
\hline & & $\begin{array}{c}3.35 \\
(2.91)\end{array}$ & $\begin{array}{c}0.24 \\
(1.17)\end{array}$ & $\begin{array}{c}-1.94 \\
(-3.12)\end{array}$
\end{tabular}

\section{Parental Capital}

Father

Mother

Father

Mother

\section{Social Support}

Network size

Network squared

\section{Assimilation}

German Passport

Born in Germany

Age-immigrated

Age-immigrated missing

Educational cohort

Quantity of Germans

Quality of Germans

$\begin{array}{ccccc}\text { NG } & 0.02 & 0.69 & 0.10 & 0.20 \\ & & (0.96) & (1.35) & (0.83) \\ \text { NG } & 0.01 & -0.64 & -0.06 & -0.20 \\ & & (-0.72) & (-0.77) & (-0.74) \\ \text { G } & 0.1 & 1.33 & 0.23 & -0.44 \\ & & (8.89) & (8.28) & (-5.60) \\ \text { G } & 0.07 & 0.82 & 0.19 & -0.16 \\ & & (4.99) & (5.79) & (-1.77)\end{array}$

NG

9.57

0.08

$0.42 * 10^{-2}$

$0.69 * 10^{-2}$

(4.47)

(2.28)

(1.00)

$\mathrm{NG} \quad 770.74$

$-0.17 * 10^{-4}$

$-0.18 * 10^{-4}$

$(-1.83)$

$(-1.28)$

$(-0.39)$

0.69

(2.38)

(2.88)

0.23

(2.97)

0.14

$-0.07$

(0.51)

$(-6.19)$

$(-0.76)$

$-0.08$

$(-3.59)$

$(-9.43)$

$(-5.07)$

$-0.57$

$-4.61$

$-0.31$

$(-2.33)$

$(-8.96)$

$(-3.90)$

$\begin{array}{ccccc}\text { NG } & 31.36 & 0.02 & 0.35^{*} 10^{-3} & 0.44 * 10^{-2} \\ & & (1.90) & (0.33) & (1.22) \\ \text { NG } & 0.08 & 1.27 & 0.20 & 1.19 \\ & & (1.13) & (1.16) & (1.78)\end{array}$




\section{Gender and Ethnicity}

\begin{tabular}{|c|c|c|c|c|c|}
\hline Male & $\mathrm{G}, \mathrm{NG}$ & 0.5 & $\begin{array}{c}0.42 \\
(6.30)\end{array}$ & $\begin{array}{c}-0.01 \\
(-1.01)\end{array}$ & $\begin{array}{c}0.30 \\
(6.79)\end{array}$ \\
\hline Turk & NG & 0.06 & $\begin{array}{c}-6.77 \\
(-4.17)\end{array}$ & $\begin{array}{c}-0.43 \\
(-2.14)\end{array}$ & $\begin{array}{c}-1.81 \\
(-2.56)\end{array}$ \\
\hline Yugoslav & NG & 0.02 & $\begin{array}{c}-4.46 \\
(-2,63)\end{array}$ & $\begin{array}{c}-0.27 \\
(-1.24)\end{array}$ & $\begin{array}{c}-1.31 \\
(-1.77)\end{array}$ \\
\hline Greek & NG & 0.02 & $\begin{array}{c}-3.69 \\
(-2.24)\end{array}$ & $\begin{array}{l}-0.21 \\
(-1.01)\end{array}$ & $\begin{array}{l}-1.86 \\
(-2.50)\end{array}$ \\
\hline Italian & NG & 0.04 & $\begin{array}{c}-5.77 \\
(-3.49)\end{array}$ & $\begin{array}{c}-0.36 \\
(-1.77)\end{array}$ & $\begin{array}{c}-1.63 \\
(-2.30)\end{array}$ \\
\hline Spaniard & NG & 0.03 & $\begin{array}{c}-2.27 \\
(-1.39)\end{array}$ & $\begin{array}{c}-0.17 \\
(-0.79)\end{array}$ & $\begin{array}{c}-1.23 \\
(-1.69)\end{array}$ \\
\hline Turk-male & NG & 0.03 & $\begin{array}{c}1.58 \\
(3.41)\end{array}$ & $\begin{array}{c}0.19 \\
(3.21)\end{array}$ & $\begin{array}{c}0.14 \\
(0.73)\end{array}$ \\
\hline Yugoslav-male & NG & 0.01 & $\begin{array}{c}0.32 \\
(0.32)\end{array}$ & $\begin{array}{c}0.16 \\
(1.52)\end{array}$ & $\begin{array}{c}0.49 \\
(1.39)\end{array}$ \\
\hline Greek-male & NG & 0.01 & $\begin{array}{c}0.40 \\
(0.57)\end{array}$ & $\begin{array}{c}0.11 \\
(1.45)\end{array}$ & $\begin{array}{c}0.33 \\
(1.05)\end{array}$ \\
\hline Italian-male & NG & 0.02 & $\begin{array}{c}0.38 \\
(0.70)\end{array}$ & $\begin{array}{c}0.01 \\
(0.15)\end{array}$ & $\begin{array}{c}0.17 \\
(0.76)\end{array}$ \\
\hline Spaniard-male & NG & 0.01 & $\begin{array}{c}-0.26 \\
(-0.40)\end{array}$ & $\begin{array}{c}0.01 \\
(0.14)\end{array}$ & $\begin{array}{c}0.04 \\
(0.15)\end{array}$ \\
\hline
\end{tabular}

\section{Controls}

$\begin{array}{lccccc}\text { Age } & \text { G, NG } & 26.24 & 0.58 & 0.03 & 0.14 \\ & & & (6.93) & (1.91) & (3.18) \\ \text { Age-squared } & \text { G, NG } & 728.53 & -0.94 * 10^{-2} & -0.55^{*} 10^{-3} & \begin{array}{c}-0.24^{*} 10^{-2} \\ (-3.06)\end{array} \\ & & & (-6.40) & (-2.30) & -7.30 \\ \text { Still-in-school } & \text { G, NG } & 0.29 & -14.54 & -4.03 & (-6.07) \\ & & & (-7.92) & (-9.07) & 0.43 \\ \text { Age*still-in-school } & \text { G, NG } & 6.01 & 1.01 & 0.32 & (4.53) \\ & & & (6.79) & (9.33) & -0.66^{*} 10^{-2} \\ \text { Age-squared*still -in- } & \text { G, NG } & 131.96 & -0.02 & -0.57 * 10^{-2} & (-3.67) \\ \text { school } & & & (-5.33) & (-9.25) & -0.21 \\ \text { Disabled } & \text { G, NG } & 0.02 & -1.17 & -0.16 & (-1.65)\end{array}$




\section{Test Statistics}

Adjusted $\mathrm{R}^{2}$

Pseudo-R ${ }^{2}$ (Veall-Zimmermann) ${ }^{\mathrm{d}}$

LM (Breusch-Pagan; DF)

${\text { LRT }(D F)^{\mathrm{c}}}$
0.428

0.187

0.114

1775.5

(30)

a The data are for men and women aged 17-38 in 1984. Non-Germans are from the foreigner sample of the SOEP, who were born in Germany or immigrated before the age of 16 . Some variables are constructed only for Germans (G); others for non-Germans (NG). They take on the value 0 for those not in the group. Numbers in parentheses are t-values, in the OLS regression White t-values.

b With heteroskedastic variance of error term exp $\alpha$. Age with $\alpha=-0.043(-15.1)$.

c LRT is the log-likelihood ratio test statistic comparing the heteroskedastic (ordinal or binomial) probit model, where the variance is assumed to depend on age, to the variant without heteroskedasticity.

d The Pseudo- $\mathrm{R}^{2}$ is equal to $(\mathrm{LRT}) /(\mathrm{LRT}+\mathrm{N}) \div(-2 \mathrm{Lo}) /(\mathrm{N}-2 \mathrm{Lo})$, where LRT is the likelihood-ratio teststatistic, $\mathrm{N}$ is the sample size, and Lo is the log-likelihood of a regression with a constant only. The second term standardizes the measure in the $[0,1]$ range. The Pseudo- $\mathrm{R}^{2}$ has been shown to mimic closely the underlying OLS- $\mathrm{R}^{2}$ for the continuous latent variable. 